\title{
段波津波による船体に作用する波力に関する 実験的考察
}

\author{
榊原 繁樹 1 - 砂原 俊之 2 ・田中 博通 3 ・阿部 郁男 4 ・ \\ 久保 雅義 $5 \cdot$ 津金 正典 6 \\ 1正会員 東海大学教授 海洋学部航海工学科（干424-8610 静岡県静岡市清水区折戸3-20-1） \\ E-mail:sakakibara@tokai-u.jp \\ 2非会員 東海大学教授 海洋学部航海工学科（干424-8610 静岡県静岡市清水区折戸3-20-1） \\ E-mail:suna@scc.u-tokai.ac.jp \\ 3正会員 東海大学教授 海洋学部環境社会学科（干424-8610 静岡県静岡市清水区折戸3-20-1） \\ E-mail:tanakah@scc.u-tokai.ac.jp \\ 4正会員 常葉大学教授 社会環境学部社会環境学科（ \\ E-mail:i-abe@fj.tokoha-u.jp \\ 5非会員 神戸大学名誉教授 海事科学部（干658-0022 兵庫県神戸市東灘区深江南町5-1-1） \\ 6非会員 前東海大学教授 海洋学部航海工学科（干424-8610 静岡県静岡市清水区折戸3-20-1）
}

\begin{abstract}
東北地方太平洋沖地震津波来襲に伴い係留事故を生じた大型船の被災事態調査につき, 関係者へのヒアリ ング，津波及び船体動摇シミュレーションにより定量的な被災実態の究明を行ってきた。これらの検討か ら船体に作用寸る津波波力を推定することは難しく，その適切な評価方法を確立することが津波来襲時の 船体挙動を推定するため, さらには津波対策立案で重要となることがわかってきた。 そこで本研究では, 係留船に作用する津波波力について，S港で津波高さ9m超の来襲により被災した 9 万トン級大型石炭船を モデルに，段波津波が作用寸る場合の実験的検討を行った。津波水平波力は水位変動及流速によく一致し， 抗力項及び慣性力項に分離することでモリソン式で概权推定できることがわかった．ただし当該抗力係数 にはさらなる検討を要する.
\end{abstract}

Key Words : tsunami wave force, vessel, tsunami bore, water tank test, morison's equation

\section{1. はじめに}

著者らは東北地方太平洋沖地震津波来襲に伴い被災し た超大型原油タンカー（VLCC）や石炭船など大型船を 対象として, 船長レポートやGPSによる実測船体位置デ ー夕等を用いて実態を検証すると共に，津波シミュレー ションおよび船体動摇シミュレーションを行なって当該 地震津波来襲時の船体挙動や係留索切断などの被災状況 を定量的に明らかにした ${ }^{122}$. また係留避泊に成功した大 型原油タンカー（10万トン級原油タンカー）につき，係 留避泊ができた要因を分析して船舶の津波係留対策を模 索した3)。これらの検討から，被災した係留船に作用寸 る津波波力の推定は難しく, かつその評価方法の確立が 重要となることがわかってきた.

そこで本研究では，S港で津波高さ $9 \mathrm{~m}$ 超の来襲により 被災した9万トン級大型石炭船をモデルに，段波状津波 が作用する場合の津波波力を模型実験により計測すると 共に，実験結果の検証を行った，合わせて，段波津波が
船体に作用寸る場合の津波波力の推定手法を検討するこ とを目的とした。

\section{2. 水理実験}

\section{(1) 模型船の諸元}

9万トン級大型石炭船をべースに手持ちの模型船を設 定した．模型縮尺は1/160程度となり，表-1のように船体 諸元を設定した.

\section{(2) 実験装置}

船体に作用する津波波力を計測するため，図-1に示す ように模型船を長さ $38 \mathrm{~m}$ ，幅 $1 \mathrm{~m}$ の二次元水槽に配置した。 段波は左端部にある貯水部のゲートを急激に開放するこ とで発生させ，船体は当該ゲートから約 $8 \mathrm{~m} の$ 位置に設 置した。波高計は，船体前方に2本（WG1, WG2）およ び後方に1本（WG3）の容量式波高計を設置し，設置間 隔は2.5mで波速の計測にも流用した。流速計は船首直前 
表-1 船体諸元

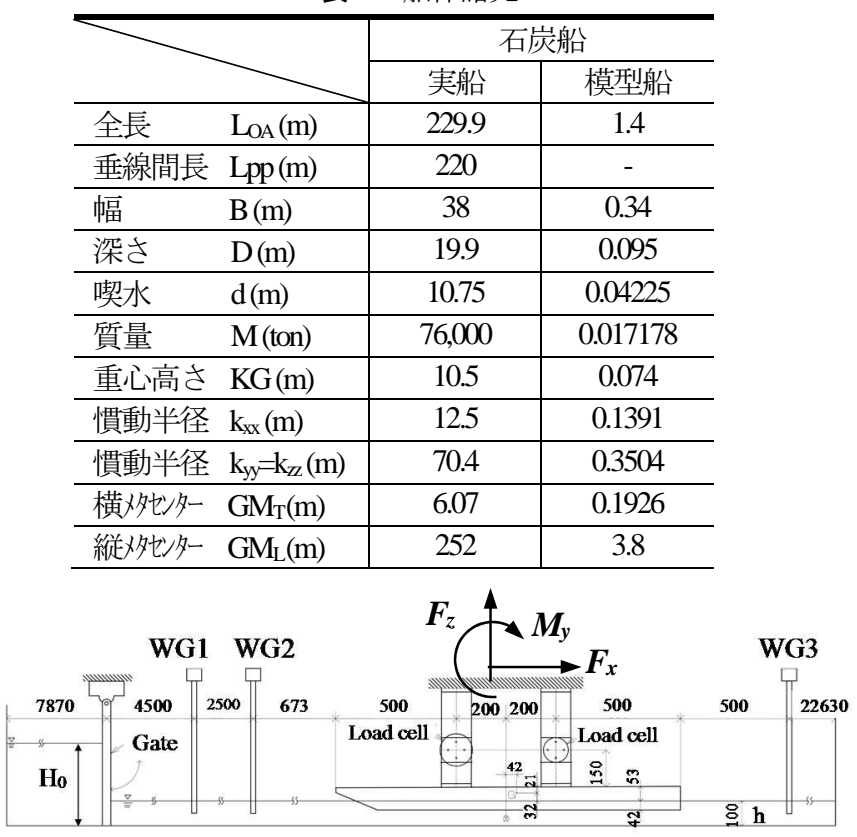

(a) 配置

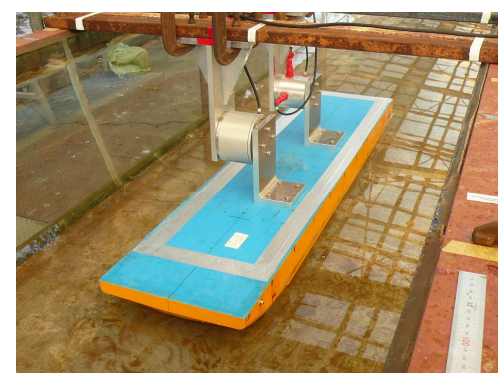

(b) 模型船及び3分力計

図-1 模型実験の配置

の波高計（WG2）位置にプロペラ式1本を設置した（静 水面下 $10 \mathrm{~mm})$. また船体に作用する波力は，3分力計を 2台船体に固定し，船首から来襲する段波による水平波 力となる $\operatorname{Surge}\left(F_{x}\right)$, 鉛直波力Heave $\left(F_{z}\right)$ および波力モーメ ントとなるPitch $\left(M_{y}\right)$ を時系列レベルで計測した.

\section{(3) 段波津波条件}

段波は貯水部のゲートを急激に開放することで発生さ せるが，船体周りの水深（h）は0.1mと固定した。そし てゲート内の水深 $\left(\mathrm{H}_{0}\right)$ は，表-2のように $0.15 \mathrm{~m}, 0.20 \mathrm{~m}$, $0.25 \mathrm{~m}$ 及び $0.30 \mathrm{~m}$ と段波の性状を4ケース変化させた.

上述のように発生させる段波の性状は図-2に示すよう に式(1),(2),(3),(4)のように表される4)5)。.

$$
\begin{aligned}
& U=\varsigma \sqrt{\frac{g(H+h)}{2 H(H-\mu \varsigma)}} \\
& C=\sqrt{\frac{g H(H+h)}{2(H-\mu \varsigma)}}
\end{aligned}
$$

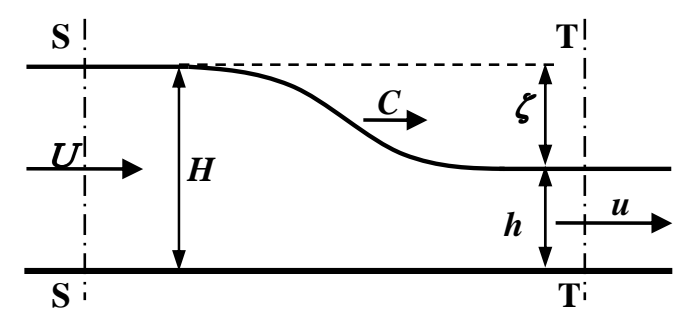

(a) 段波（砕波段波）

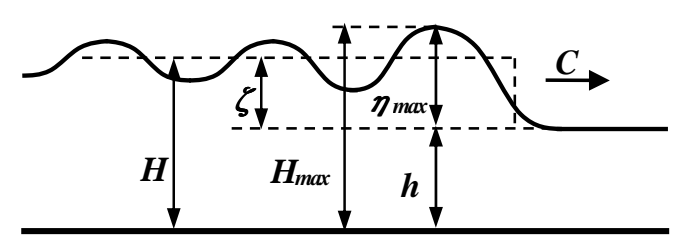

(b) 波状段波

図-2 段波津波の諸元

表-2 津波実験条件

\begin{tabular}{l|c|c|c|c}
\multirow{2}{*}{} & \multicolumn{4}{|c}{ 水深 $(\mathrm{m})$} \\
\cline { 2 - 5 } & $\mathrm{H}_{0}$ & $\mathrm{H}_{\max }$ & $\mathrm{H}$ & $\mathrm{h}$ \\
\hline ケース1 & 0.15 & 0.143 & 0.128 & 0.10 \\
\hline ケース2 & 0.20 & 0.162 & 0.150 & 0.10 \\
\hline ケース3 & 0.25 & 0.172 & 0.163 & 0.10 \\
\hline ケース4 & 0.30 & 0.198 & 0.195 & 0.10 \\
\hline
\end{tabular}

表-3 津波特性

\begin{tabular}{l|c|c|c|c|c}
\hline & $\begin{array}{c}\eta_{\max } \\
(\mathrm{m})\end{array}$ & $\begin{array}{c}\zeta \\
(\mathrm{m})\end{array}$ & $\zeta / \mathrm{h}$ & $\begin{array}{c}\mathrm{U}_{\max } \\
(\mathrm{m} / \mathrm{s})\end{array}$ & Fr \\
\hline ケース1 & 0.0426 & 0.0280 & 0.280 & 0.365 & 0.309 \\
\hline ケース2 & 0.0622 & 0.0500 & 0.500 & 0.495 & 0.393 \\
\hline ケース3 & 0.0716 & 0.0630 & 0.630 & 0.608 & 0.469 \\
\hline ケース4 & 0.0984 & 0.0952 & 0.952 & 1.029 & 0.738 \\
\hline
\end{tabular}

$$
\varsigma=H-h
$$

$$
\eta_{\max }=H_{\max }-h
$$

ここにUは船体直前の波高計(WG2)位置となる参照位置S での流速， $u$ は船体船尾の参照位置Tにおける流速 $(u=0)$, Cは波速，Hは段波が通過する参照位置Sでの水深，hは 参照位置Tにおける水深 $(h=0.1 \mathrm{~m}), \quad \zeta$ は津波高さ, $\mu$ は 抵抗係数（ $\mu=1$ とした），gは重力加速度， $H_{\max }$ は波状 段波の最大水深及び n maは は最大津波高さである.

\section{3. 実験結果と考察}

\section{(1) 段波津波の特性}

図-3に船体前方の2本（WG1, WG2）及び後方の1本 （WG3）の波高計で計測した水位変動の時系列を示す. 


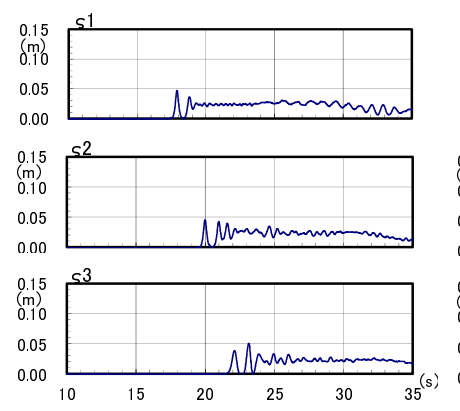

(a) $\mathrm{H}_{0}=0.15 \mathrm{~m}$ （ケース 1 )

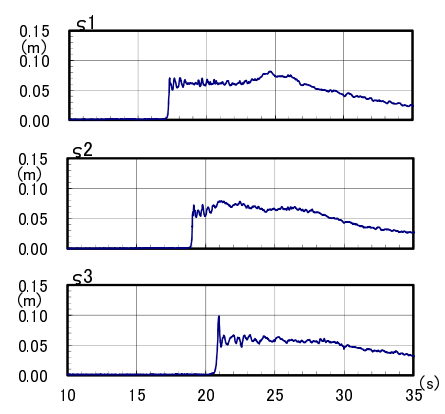

(c) $\mathrm{H}_{0}=0.25 \mathrm{~m}$ （ケース 3$)$

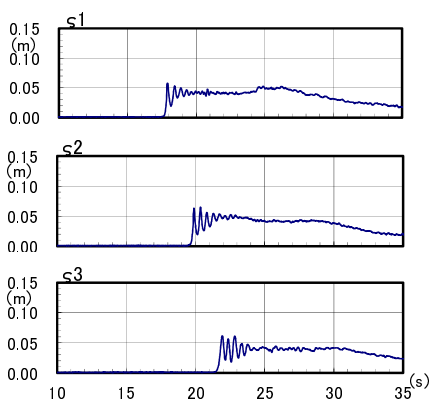

(b) $\mathrm{H}_{0}=0.20 \mathrm{~m}$ (ケース 2$)$

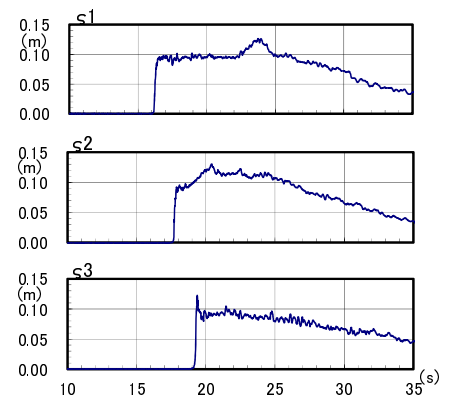

(d) $\mathrm{H}_{0}=0.30 \mathrm{~m}$ （ケース 4$)$

図-3 水位変動の時系列（WG1,WG2,WG3）

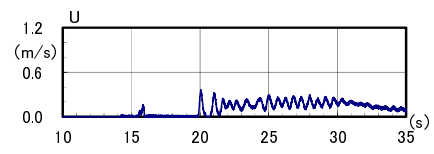

(a) $\mathrm{H}_{0}=0.15 \mathrm{~m} （$ ケース 1$)$

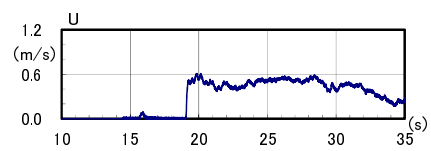

(c) $\mathrm{H}_{0}=0.25 \mathrm{~m}$ (ケース 3$)$

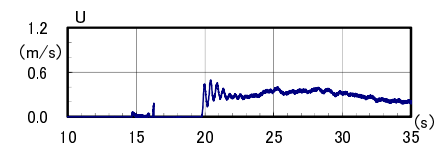

(b) $\mathrm{H}_{0}=0.20 \mathrm{~m} \quad$ (ケース 2$)$

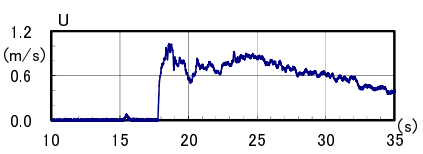

(d) $\mathrm{H}_{0}=0.30 \mathrm{~m} \quad$ (ケース 4$)$

図-4 流速の時系列（WG2 と同じ位置）

波高計間の段波到達時間差（WG1 とWG2）及び （WG2とWG3）は，いずれのケースでも同じで船体周 りで波速が安定していることがわかる。津波高さらは, 水位差 $\left(H_{0}-h\right)$ に対応して大きくなっている. ただしケー

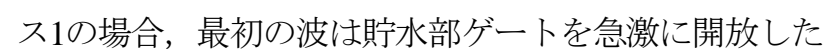
際に発生した孤立波であり無視した．表-3に実験で発生 させた段波状の津波特性をまとめるが，段波波高と段波 前面水深比 $\zeta / h$ が $0.61 \sim 0.64$ 上り小さい場合波状段波と なることからの，ケース1及び2は波状段波，ケース3及び 4は砕波段波と考えられる。. またケース3及び4の場合， 船体からの反射波による水位上昇が $25 \mathrm{~s}(\mathrm{WG} 1)$ と 21.5s(WG2), 及び24s(WG1) と20s(WG2)に顕著にみられる.

図-4に流速（WG2位置）の時系列を示寸. 図-3と合わ せてみると, 流速は津波高さに顕著に影響し，ケース 1 及び2の場合波状に変動している．またケース3及び4の

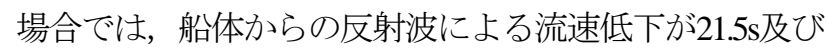
20sにみられる。

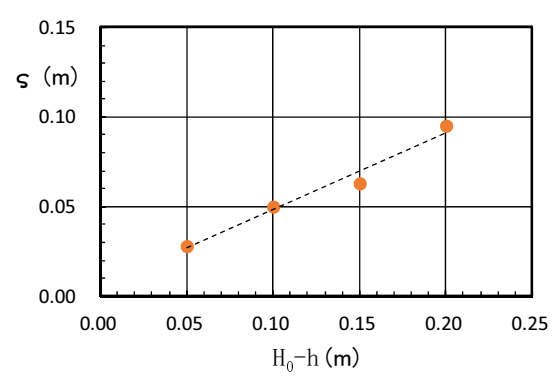

(a) 津波高さと水位差 $\left(\mathrm{H}_{0}-\mathrm{h}\right)$ の関係

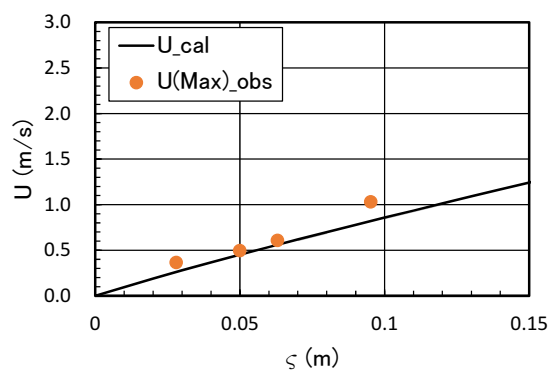

(b) 流速と津波高さの関係

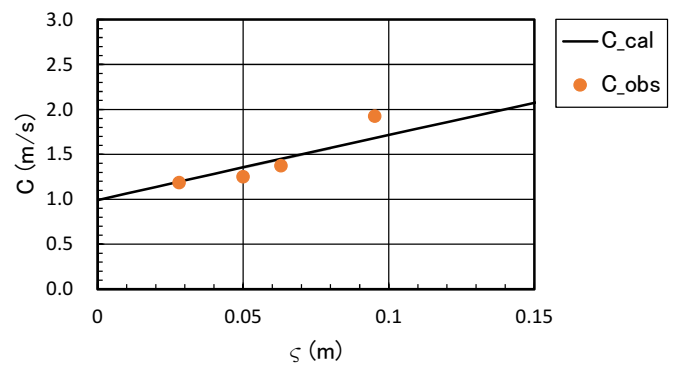

(c) 波速と津波高さの関係

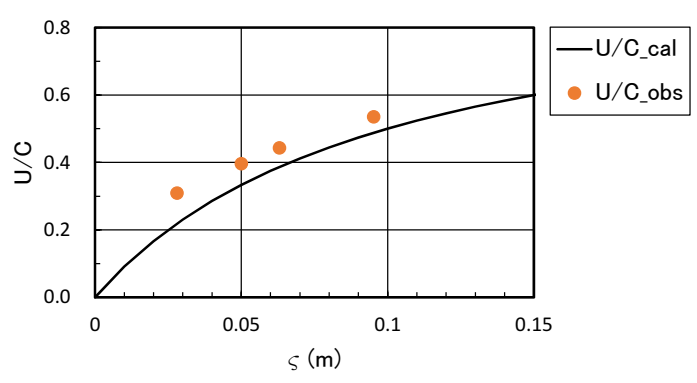

(d) U/Cと津波高さの関係

図-5 段波津波の特性

図-5に津波高さ $\zeta$ と水位差 $\left(H_{0}-h\right)$ の関係を示すと共に, 流速 $(U)$, 波速 $(C)$ 及び流速波速比 $(U / C)$ の式(1),(2)の計算值 との比較を示す. 発生津波高さは, 貯水部との水位差の 約半分程度となり，また流速，波速及び流速波速比共に, 実験值は計算值と概ね一致することがわかった。

\section{（2）津波波力の特性}

\section{a) 時系列}

図-6に船首から来襲寸る段波による水平波力 $\operatorname{Surge}\left(F_{x}\right)$, 鉛直波力Heave $\left(F_{z}\right)$ 及び波力モーメントP Pitch $\left(M_{y}\right)$ の時系列 


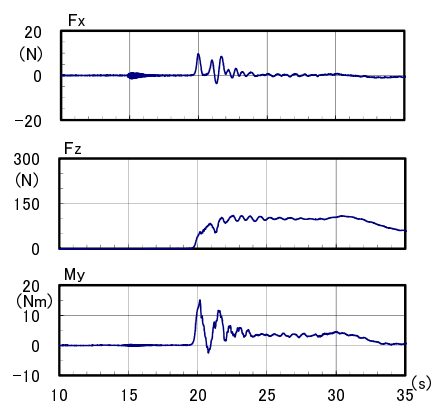

(a) $\mathrm{H}_{0}=0.15 \mathrm{~m}$ （ケース 1$)$

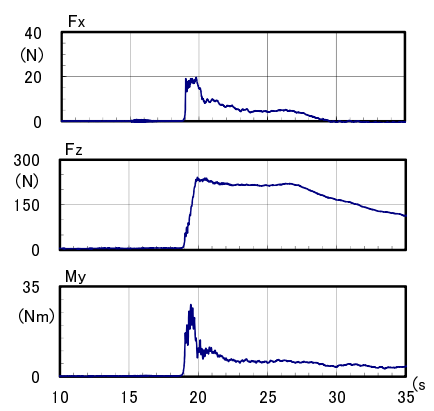

(c) $\mathrm{H}_{0}=0.25 \mathrm{~m}$ （ケース 3$)$
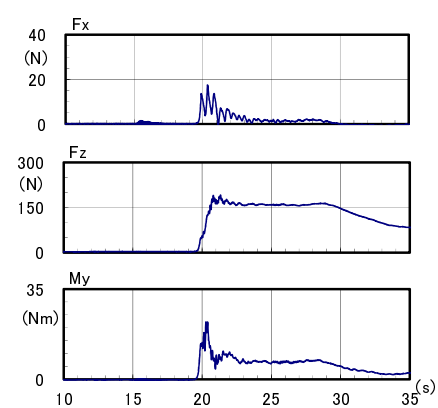

(b) $\mathrm{H}_{0}=0.20 \mathrm{~m}$ （ケース 2$)$

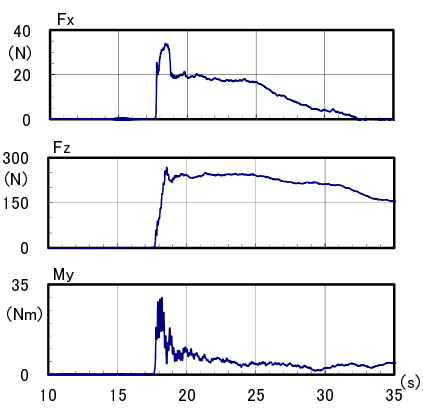

(d) $\mathrm{H}_{0}=0.30 \mathrm{~m}$ （ケース 4$)$

図-6 船体に作用寸る津波波力の時系列

を示す，船体に作用する津波波力の挙動を理解し易くす るため，波力の生じる時刻を図-3に示した船体直前の波 高計(WG2)の水位変動の開始時刻に一致させて表示した.

津波波力は図-3，-4に示した水位変動及び流速によく 一致して変動していることがわかる．そして水平波力 $\operatorname{Surge}\left(F_{x}\right)$ 及び波力モーメントPitch $\left(M_{y}\right)$ は, 全てのケースで 段波が船体船首に達した時に衝撃的に発生することがわ かった，一方鉛直波力Heave $\left(F_{z}\right)$ は，段波が船首部に到達 後徐々に上昇し，その後一定化している．これは津波で 船体が水没することで発生する余剰浮力が鉛直波力 Heave $\left(F_{z}\right)$ に概ね相当しており，ケース3及び4では船体は 全没する状況であった．本来船体は，当該段波来襲時に 水位に合わせて上昇するが，支持固定されているため水 没して過大な水平波力が生じている可能性がある。また 後述の図-9(b)に示寸最大Heave波力はケース4でもさらに 増加しており, 余剩浮力以外の要因も考えられる. 図-7, 8にケース2（波状段波）及びケース3（砕波段波）の実 験状況を示す。

\section{b) フルード数、水平波力、鉛直波力及び無次元水平波 圧の関係}

図-9に式(5)に示すフルード数および最大Surge波力の 津波高さに対する実験結果を示すと共に，朝倉ら円の検 討に則して, フルード数と無次元水平波圧の関係をまと める. 図-9(b)には最大Heave波力も合わせて示している. 図-9(c)の波圧 $\left(P_{x}=F_{V} / A_{x}\right)$ 算出に際しては，津波来襲時の船 体没水正面投影面積 $\left(A_{x}\right)$ をWG2での水位データと映像か

ら求め, また船幅 $(B)$ から没水喫水 $(d s=A \sqrt{ } B)$ を設定した. フルード数1.0未満の実験条件であったことから無次元 波圧は概ね1.0となったものと考えられる.

$$
F r=\frac{U_{\text {max }}}{\sqrt{g H_{\text {max }}}}
$$

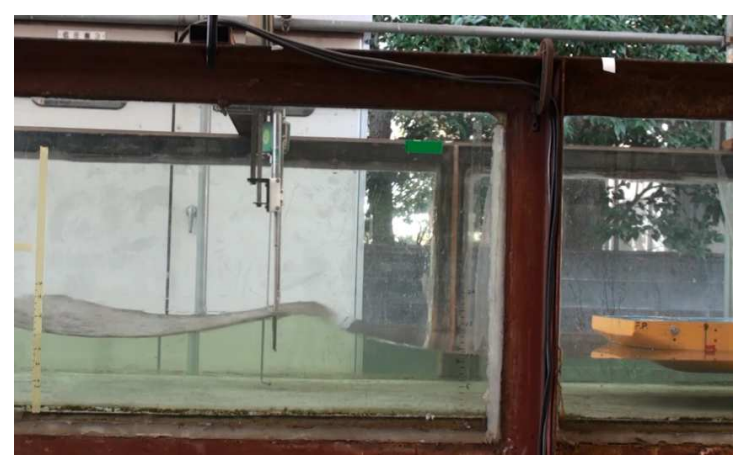

(a) 波高計(WG2)を段波通過

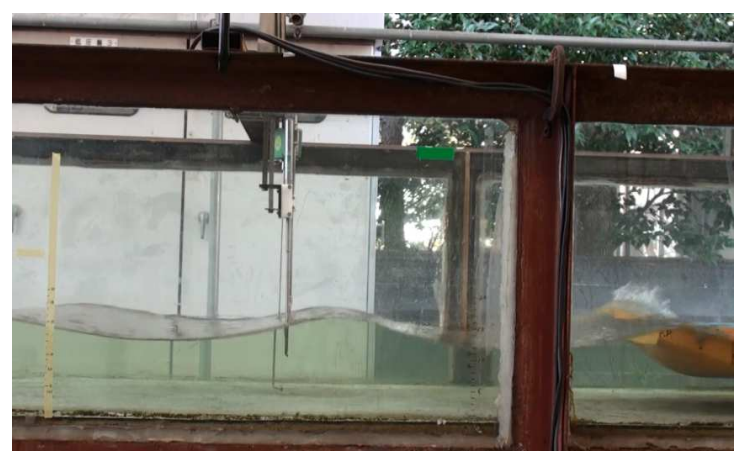

(b) 船体船首部に段波到達

図-7 試験状況（ケース $2: \mathrm{H}_{0}=0.20 \mathrm{~m}, \mathrm{~h}=0.1 \mathrm{~m} ）$

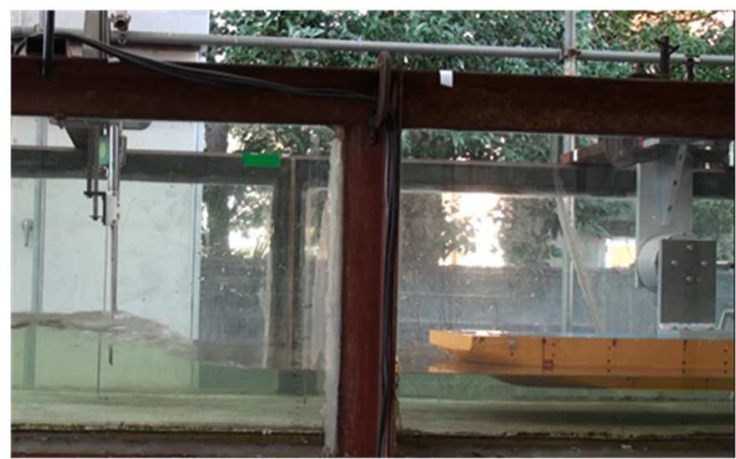

(a) 波高計(WG2)を段波通過

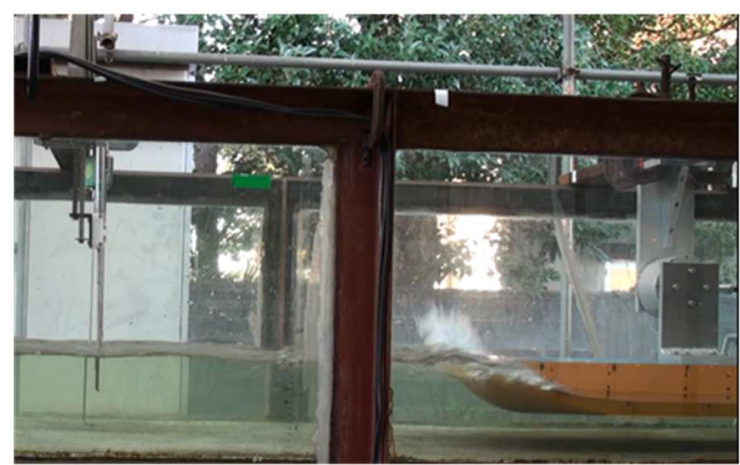

(b) 船体船首部に段波到達

図-8 試験状況（ケース $3: \mathrm{H}_{0}=0.25 \mathrm{~m}, \mathrm{~h}=0.1 \mathrm{~m} ）$ 


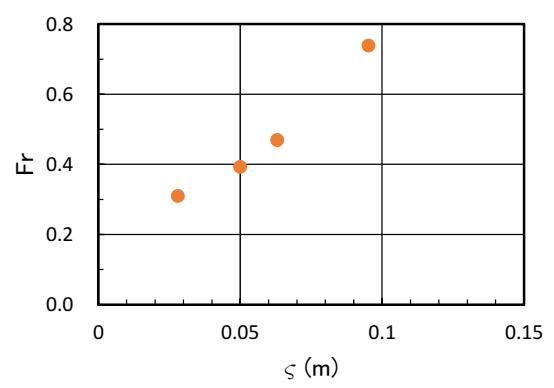

(a) 津波高さとフルード数の関係

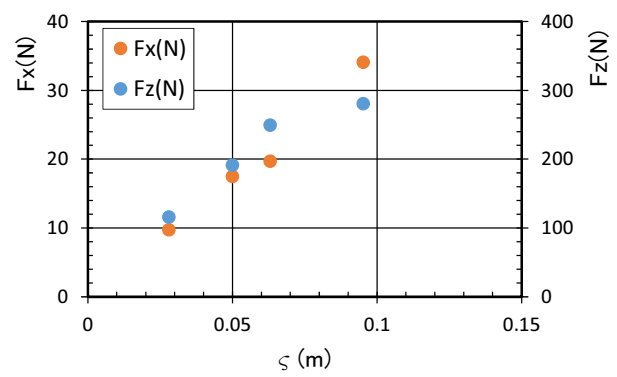

(b) 津波高さと最大水平及び鉛直波力の関係

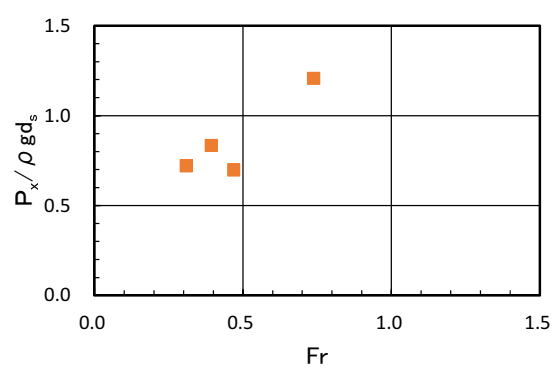

(c) フルード数と無次元水平波圧の関係

図-9 フルード数，水平波力，鉛直波力及び無次元波圧の関係

\section{(3) 津波波力の推定}

船舶などの浮体に作用する津波波力に関する検討は, 池谷らも同様に水理模型実験により行っている ${ }^{8)}$. しか し津波は長周期波として扱っていた。 そこで段波津波作 用時のSurge波力 (水平波力)の推定方法として，モリソ ン式による推定を試みる。ここに波力および流速の実験 結果を用いて，式(6),(7),(8)のように波力を抗力項及び慣 性力項に分離した. これに際しては抗力係数および慣性 力係数を実験的に設定した.

$$
\begin{aligned}
& F_{x}=F d_{x}+F m_{x}, \\
& F d_{x}=0.5 \cdot \rho \cdot C_{d x} \cdot A_{x} \cdot U^{2}, F m_{x}=C_{m x} \cdot M \cdot \frac{\partial U}{\partial t} \\
& A_{x}=A_{x}\left(d_{s}\right) \\
& M=\rho \cdot V\left(d_{s}\right)
\end{aligned}
$$

ここにFdxは抗力成分，Fmxは慣性力成分， $\rho$ は流体密度， $C_{d x}$ は抗力係数， $A_{x}$ は津波高さで変動する没水正面投影面
積, $C_{m}$ は慣性力係数, $M$ は船体質量, $V$ は没水体積, 及 びdsは津波来襲時の喫水である.

抗力項 $F d_{x}$ は図-6に示した津波波力の初期の衝撃的な 変動以降の定常波力部分を考えた。 そして抗力係数 $C_{d x}$ は図-4に示した流速の当該対応時刻の流速を用いて式(9) のように算定した.

$$
C_{d x}=\frac{2 F d_{x}}{\rho \cdot A_{x} \cdot U^{2}}
$$

一方で，加速度は図-4に示した流速の時間微分から算 出し, そして余剰波力分 $F_{x} F d_{x}$ を慣性項 $F m_{x}$ と考え, 式 (10)のように慣性力係数 $C_{m}$ を算定した.

$$
C_{m x}=\frac{F_{x}-F d_{x}}{M \cdot \dot{U}}
$$

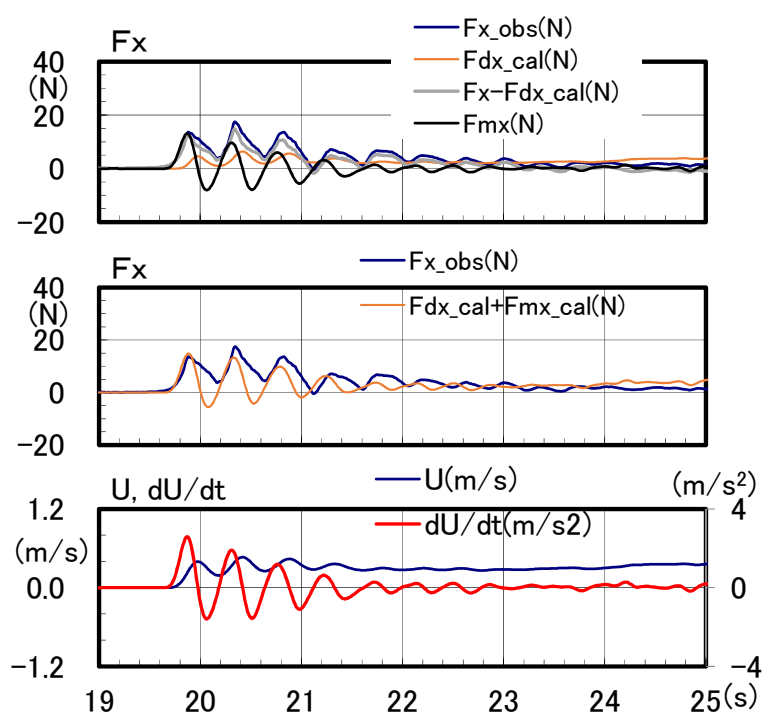

(a) ケース $2 \quad\left(\mathrm{H}_{0}=0.20 \mathrm{~m}, \mathrm{~h}=0.1 \mathrm{~m}\right)$

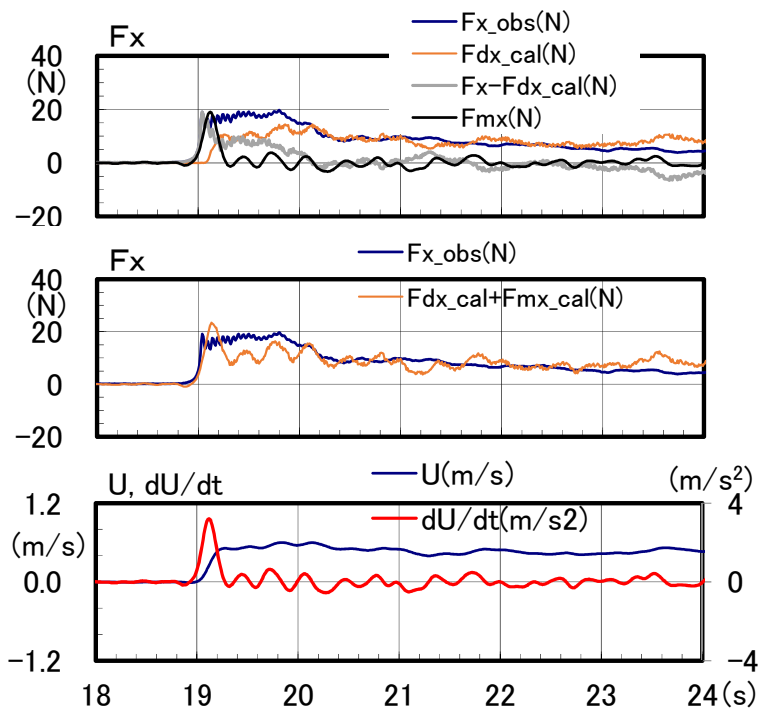

(b) ケース $3 \quad\left(\mathrm{H}_{0}=0.25 \mathrm{~m}, \mathrm{~h}=0.1 \mathrm{~m}\right)$

図-10 津波水平波力の推定 


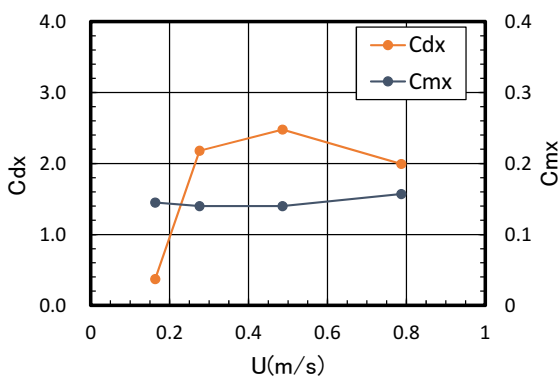

図-11 抗力係数及び慣性力係数の特性

一例として図-10にケース2及び3の再現結果を示寸. どちらのケースも津波波力の実験結果をよく再現してい ることがわかる。

\section{（4） 抗力係数及び慣性力係数の特性}

図-11に津波波力推定で使用した式(9)及び(10)で算定し た抗力係数及び慣性力係数を流速ごとに示す．慣性力係 数は $C_{m}=0.15$ とほぼ一定である. 一方抗力係数 $C_{d k}$ は, 流 速により変動し, 別途本学回流水槽で行った当該模型船 の流圧試験結果での約 0.24 に較べてかなり大きな值とな っている. なお当該回流水槽で得られた抗力係数は OCIMFに示された值9に類似している. 図-11に得られた 抗力係数に関しては, 流速の鉛直分布特性の把握などさ らなる実験的検討が必要と考えている.

\section{4. おわりに}

本研究では，S港で津波高さ9m超の来襲により被災し た9万トン級大型石炭船をモデルに，段波状津波が作用 する場合の津波波力を模型実験により計測すると共に, 段波津波が船体に作用寸る場合の津波波力の推定を試み た. 津波水平波力は水位変動及び流速によく一致して変 動することから，抗力項と慣性力項に分離することによ り，モリソン式で概初推定できることを確認した，ただ
し抗力係数が流圧試験結果よりかなり大きな值となり， かつ流速により変動する結果となったことからさらなる 検討を要する. 今後追加の模型実験結果と合わせて, さ らにはヒアリング調查(10)との照合を通じて, 当該係留船 の定量的な被災実態調査を行いたく考えている.

\section{参考文献}

1）榊原繁樹，阿部郁男，津金正典，久保雅義: 東北地方太平 洋沖地震津波による栈橋係留の超大型原油タンカーの被 災実態，土木学会論文集 B2（海岸工学）, Vol. 68, No. 2, pp. I_816-I_820,2012.

2) 榊原繁樹, 阿部郁男, 津金正典, 久保雅義: 東北地方 太平洋沖地震津波来襲時の栈橋係留大型石炭船の挙 動再現について, 日本航海学会論文集, 第 131 号, pp.89-99, 2014.

3) 榊原繁樹, 阿部郁男, 津金正典, 久保雅義: 東北地方太 平洋沖地震津波における大型原油タンカーの係留避 泊実態, 土木学会論文集 B2（海岸工学）, Vol. 69, No. 2, pp. I_871-I_875, 2013.

4) 福井芳朗, 白石英彦, 中村充, 佐々木泰雄: 津波の研 究(I) - 段波津波の波速について-, 海岸工学講演会講 演集，第 9 回, pp.44-49, 1962.

5) 室田 明, 岩田好一朗: 段波の変形に関する研究, 土 木学会論文集，第 160 回，pp.49-58, 1968.

6) 松冨英夫: 移動跳水（波状段波非）発生条件の検討, 水理講演会論文集，第 33 回，pp.271-276, 1989.

7) 朝倉良介, 岩瀬浩二, 池谷毅, 高尾誠, 金戸俊道, 藤井直樹, 大森政則: 護岸を越流した津波による波力 に関する実験的研究, 海岸工学論文集, 第 47 巻, pp.911-915, 2000.

8) 池谷毅，朝倉良介，藤井直樹，大森政則，武田智吉， 柳沢賢: 浮体に作用寸る津波波力の実験と評価方法の 提案, 海岸工学論文集, 第 52 巻, pp.761-765, 2005.

9) OCIMF : Prediction of Wind and Current Loads on VLCCs., 2nd Edition, Witherby \& Co., Ltd., 1994.

10) 榊原繁樹, 阿部郁男, 久保雅義, 津金正典: 東日本大 震災で被災した隣接 2 隻の大型石炭船に来襲した津 波および船体に作用する津波波力に関する一考察，日 本航海学会論文集, 第 134 号, 印刷中, 2016.

(2016.3.16 受付)

\section{AN EXPERIMENTAL STUDY ON TSUNAMI WAVE FORCE OF A VESSEL DUE TO TSUNAMI BORE}

\section{Shigeki SAKAKIBARA, Shunji SUNAHARA, Hiromichi TANAKA, Ikuo ABE, Ma- sayoshi KUBO and Masanori TSUGANE}

In the 2011 Tohoku Earthquake Tsunami, the tsunami disasters occurred in many vessels moored along the terminals inside the harbor basins. It is required how to express and estimate the tsunami wave force on those vessels. An experimental study on the tsunami wave force for a vessel which is modeled as a 90,000DWT class coal carrier has been conducted in two-dimensional water tank during a tsunami bore. The surface elevation, current and wave forces acting on the fixed vessel in head seas have been measured in several established bores. The property of the tsunami bore and wave forces are investigated, and a practical estimation method of tsunami wave force of the vessel is also demonstrated by using Morison's formula, and compared with that of observed one. 